It comes down, feels the house like a hand. Your hands would run down my cheeks, fall from my face like rain.

This is memory. This pure silence.

You learn the most from those you hardly know: back in the brief days of that other life, my father taught me that silence is the longest word.

\title{
Rivers, Horses and FirewoOd
}

Three cold streams come down from the mountains. They meet at the bottom and the river begins, running west after the sun, running straight. When the road was built the old bridges were abandoned and began to fall and ride the current like firewood on a gentle horse.

My father sold firewood across the river when he was ten. He walked by his horse, running his hands up and down the reins and thinking of his mother, how she stayed home, running her hands up and down her rosary as if taking her faith by the reins, selling her soul to God like firewood.

\section{FABLE}

It wasn't that long ago. Hurricanes with the names of women would cross the island like packs of wildebeest. Hurricanes with the names of our dead: 